\title{
Dirofilaria repens in dogs and humans in Slovenia
}

\author{
Tina Kotnik $^{1 凶}$, Aleksandra Vergles Rataj ${ }^{2}$, Barbara Šoba ${ }^{3}$ \\ ${ }^{1}$ Small Animal Clinic, Veterinary Faculty, University of Ljubljana, SI-1000 Ljubljana, Slovenia \\ ${ }^{2}$ Institute of Microbiology and Parasitology, Veterinary Faculty, University of Ljubljana, SI-1000 Ljubljana, Slovenia \\ ${ }^{3}$ Institute of Microbiology and Immunology, Faculty of Medicine, University of Ljubljana, SI-1000 Ljubljana, Slovenia \\ tina.kotnik@vf.uni-lj.si
}

Received: July 7, $2021 \quad$ Accepted: February 2, 2022

\begin{abstract}
Introduction: The prevalence of Dirofilaria repens in dogs in countries bordering Slovenia ranges from 1.5\% to $47.3 \%$. The aim of this study was to estimate its prevalence in Slovenian dogs and to present the cases of dirofilariasis diagnosed in humans from 2010 to 2020. Material and Methods: Epidemiological data were collected and blood samples were taken from 465 dogs older than one year and born in Slovenia. A real-time PCR was performed on all samples to detect filarioid DNA, and a D. repensand $D$. immitis-specific real-time PCR was performed on positive samples. Blood samples from 446 dogs were tested for Dirofilaria spp. using a modified Knott's test. Human cases were diagnosed from histological sections of excised subcutaneous nodules. Descriptive statistics were used to characterise the samples. The one-sample nonparametric chi-squared test was used to assess whether categories of a variable were equally distributed. Results: Three dogs' samples tested positive for D. repens using the speciesspecific real-time PCR, while D. immitis DNA was not detected. The modified Knott's test was positive in two of the three PCR-positive dogs, two of which had never travelled outside Slovenia's borders. Four human patients with D. repens dirofilariasis were diagnosed. Since their travel history was unknown, autochthonous transmission could not be confirmed. Conclusion: Our study demonstrated a $0.64 \%$ prevalence of D. repens infection in dogs in Slovenia. Two cases could be autochthonous.
\end{abstract}

Keywords: dirofilariasis, D. repens, prevalence, dogs, humans.

\section{Introduction}

Until the last decade of the twentieth century, dirofilariasis in dogs occurred mainly in southern European countries such as Italy, Portugal, Spain, France, and Greece, where it has been present historically. The introduction of the Pet Travel Scheme in 2000 contributed to the spread of dirofilariasis by facilitating the movement of dogs carrying microfilariae from endemic areas throughout Europe. There is evidence that $D$. repens has spread faster than $D$. immitis from the endemic areas of southern Europe to northern Europe. In addition, the change in climate which has lengthened the summer season in northwestern Europe has facilitated longer survival of mosquitoes and better survival of parasites within them (6).

Adult worms of $D$. repens are parasites which live as long as approximately 4 years in their natural hosts (12). Females can produce up to 5,000 microfilariae per day (33). Dogs, cats, and wild carnivores are the final hosts of $D$. repens and constitute the only source of accidental infection of humans, which has to occur in the presence of a competent population of mosquito vectors (21). Common signs of infection in pets include pruritus, papules, erythaema, alopecia, crusting, hyperkeratosis, lichenification, and acantosis (33). Skin symptoms tend to recur seasonally from spring to autumn in the second to third year and become persistent from the fourth year of infection. Pathogenic effects, either seasonal or persistent, are due to the cumulative effect of greater numbers of microfilariae and adults, their autoimmune and toxic effects, and reinfection. If fever, lethargy, anorexia, or vomiting are present, concurrent infections such as babesiosis, anaplasmosis, and leishmaniasis should be excluded (31). Occasionally, subcutaneous nodules formed by a cyst enclosing an adult nematode are seen (6). However, in most cases, no pathogenic signs are observed in animals carrying $D$. repens microfilariae, and therefore the infection may be asymptomatic and chronic for several years (2). As a result, the detection of $D$. repens microfilariae in dogs is still often considered to be irrelevant and not in need of treatment, although drug therapy would greatly reduce the risk of infection to humans and help 
to eliminate or prevent the onset or flare-up of cutaneous symptoms in affected animals (33).

Not surprisingly, D. repens is the principal agent of human dirofilariasis in the Old World. As for human dirofilariasis in the Mediterranean, cases seem to be reported mainly in areas where canine dirofilariasis is present (30). Humans acquire the infection in the same way as dogs, through the bite of a mosquito, but it is likely that most of the infective larvae die shortly afterwards, leaving the infection undetected and causing no specific symptoms. In infected patients, the developing stages of $D$. repens may migrate subcutaneously to various parts of the body for a period from weeks to several months, usually with mild and undetected symptoms. The parasites can cause subcutaneous lesions that may initially be misinterpreted as malignant tumours and require invasive procedures and surgery for proper identification (10). During migration, $D$. repens can reach the eyes and become visible through the conjunctiva. Only sometimes does the parasite cause larval migration-like symptoms (i.e. irritation and itching), but on rare occasions in immunocompromised individuals it can cause complications related to the organs to which it migrates (6).

The spread of dirofilariasis may be attributed primarily to the rate of the parasite's presence in undiagnosed dogs that facilitate the continuation of its life cycle. Many infected dogs remain undiagnosed due to the subclinical nature of the disease, the lack of rapid and reliable diagnostic tools, and insufficient knowledge and awareness specifically about $D$. repens in non-endemic areas (6).

Currently, new endemic areas have been identified and confirmed in Austria, Hungary and Croatia (11), and all these countries are neighbours of Slovenia. The prevalence of $D$. repens in dogs in countries bordering Slovenia ranges from $1.5 \%$ to $47.3 \%(5,7,8,28,33,34)$. The aim of the present study was to estimate the prevalence of $D$. repens in dogs in Slovenia and to present cases of dirofilariasis in humans that came to our attention from 2010 to the end of 2020.

\section{Material and Methods}

Recruitment and collection of materials. In collaboration with veterinarians evenly distributed throughout the country, a total of 465 blood samples were collected from asymptomatic dogs. The sample size was estimated in advance using the binomial equation and accepting a margin of error of $2 \%$, tolerating a confidence level of $95 \%$ and using a response distribution of $5 \%$. The response distribution was estimated based on other studies on microfilariae. We used the same samples as in the study by Kotnik et al. (14) on leishmaniasis prevalence in the Slovenian dog population, both for economic reasons and in the expectation that seroprevalence for both diseases would be low in our region. Genomic DNA was extracted from all collected blood samples and stored at $-20^{\circ} \mathrm{C}$ until analysis. Complete blood samples drawn from $446 \mathrm{dogs}$ were stored frozen for microscopic detection of microfilariae. Microscopy could not be performed in 19 cases due to the small amount of blood samples.

Modified Knott's test. The modified Knott's test was performed on $446 \mathrm{dog}$ blood samples. The blood of the dogs was frozen until it could be tested, and first required to be thawed. Since the red blood cells were destroyed, the protocol did not specify formalin but physiological solution instead $(0.9 \% \mathrm{NaCl})$. To $100 \mu \mathrm{L}$ of thawed blood $1 \mathrm{~mL}$ of $0.9 \% \mathrm{NaCl}$ was added, the solution was centrifuged at $10,000 \times \mathrm{g}$ for $10 \mathrm{~min}$, and then the supernatant was discarded. The sediment was mixed with $50 \mu \mathrm{L}$ of $0.1 \%$ methylene blue. The resulting sediment was examined with a Nikon YS2-H Anti-Mould light microscope (Tokyo, Japan).

Real-time PCR. Molecular analysis was performed on 465 canine blood samples to detect filarioid DNA. Genomic DNA was extracted from $200 \mu \mathrm{L}$ aliquots of whole blood samples using QIAamp DNA Mini Kit (Qiagen, Hilden, Germany) according to the manufacturer's instructions. All genomic DNAs were first screened by pan-filarial real-time PCR for the large subunit rRNA (28S rRNA) gene of filarial nematodes using the qFil-28S-F and qFil-28S-R primers and the qFil-28S-P TaqMan probe according to Laidoudi et al. $(15,16)$. Samples positive for filarioid DNA were then tested for $D$. repens and $D$. immitis DNA by real-time PCR amplifying the cytochrome c oxidase subunit 1 (cox1) mitochondrial gene using the Fil.COI.749-F and Fil.COI.914-R primers and the D.imm.COI.777-P and D.rep.COI.871-P TaqMan probes $(15,16)$.

Histological sections. Between January 2010 and the end of December 2020, haematoxylin and eosinstained histological sections of subcutaneous nodules excised from four human patients were referred to the Laboratory of Parasitology at the Institute of Microbiology and Immunology, Faculty of Medicine, University of Ljubljana, for diagnostic purposes. All sections were examined microscopically using a Nikon Eclipse E600 microscope to detect D. repens nematodes according to morphological characteristics, as described previously (1).

Statistical analysis. Descriptive statistics were used to characterise the samples. The nonparametric one-sample chi-squared test was used to test whether the categories of a variable were equally distributed. A $P$ value of $<0.05$ was considered statistically significant. Statistical tests were performed using IBM SPSS Statistics 21 for Windows (IBM, Armonk, NY).

\section{Results}

Evaluation group profile and epidemiology. The sexes of the participating dogs were statistically equally distributed $\left(\chi^{2}=1.809, \mathrm{df}=1, \mathrm{P}=0.179\right)$, their median 
age was 6 years (min 1 year, $\max 18$ years) and they belonged to different breeds. Epidemiological data of the recruited $\operatorname{dogs}$ were presented in the study on the prevalence of canine leishmaniasis in the Slovenian dog population (14).

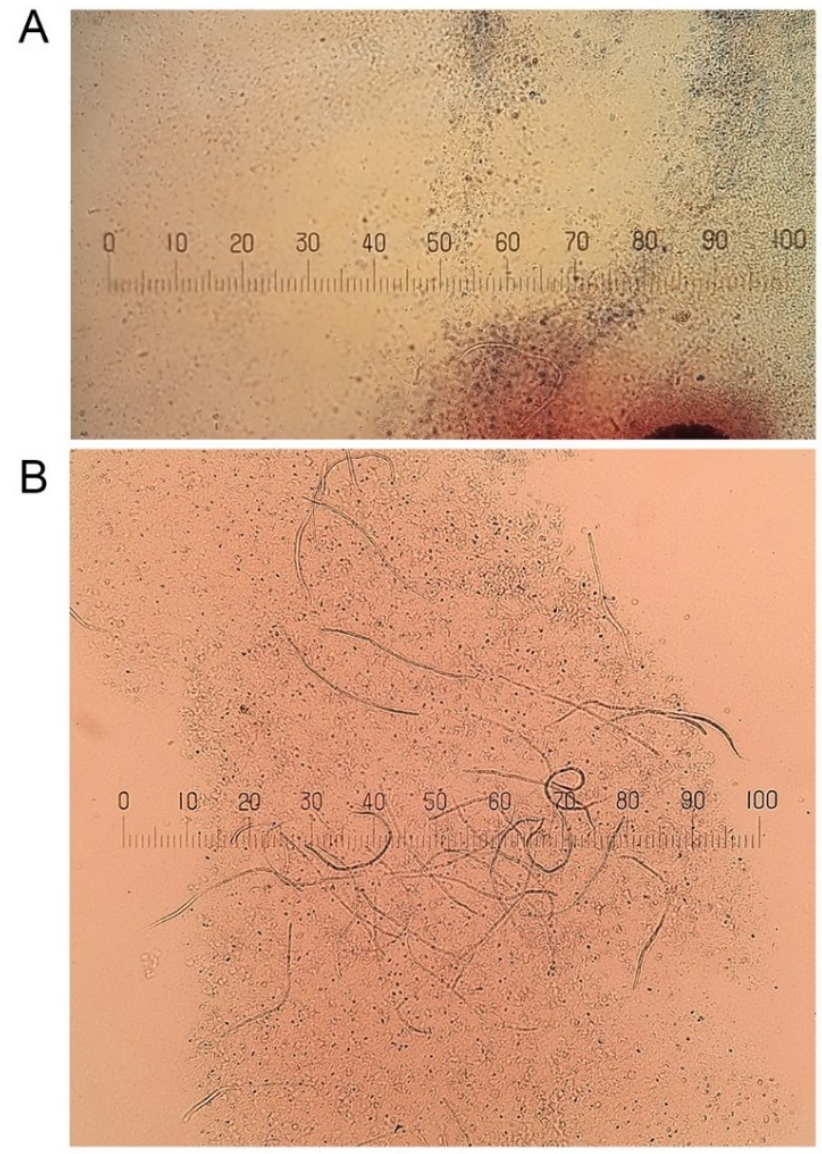

Fig. 1. Microfilariae detected by modified Knott's test. One sample contained few larvae (A), while the other presented many (B). The parasites were photographed using a Nikon microscope and Easy Share C 613 camera (Kodak, Rochester, NY, USA). Stage micrometer: $1 \mathrm{~mm}$

Knott's test results. Two of the 446 samples tested positive. One sample hosted many larvae and the other contained few of them (Fig. 1). Based on their morphological appearance and morphometric measurements, the microfilariae were identified as Dirofilaria spp.

Real-time PCR results. Of the 465 canine blood samples tested, $3(0.64 \%)$ tested positive by pan-filarial real-time PCR. By species-specific real-time PCR, $D$. repens was confirmed in all three microfilariaepositive samples, whereas $D$. immitis DNA was not detected in any of them. Two of the three positive samples (nos. 76 and 390, Table 1) were also positive by the modified Knott's test, while one (no. 389) was negative. The detailed results of the dogs that tested positive in at least one assay (parasitological or molecular) are shown in Table 1.

Demographic and clinical data of the human cases. Human cases with $D$. repens dirofilariasis are presented in Table 2. The excised subcutaneous nodules were of soft consistency. Microscopical examination of the histological sections revealed a parasite with internal organs and thick laminated cuticle with characteristic longitudinal ridges (Fig. 2) surrounded by inflammatory reaction and granulation tissue.

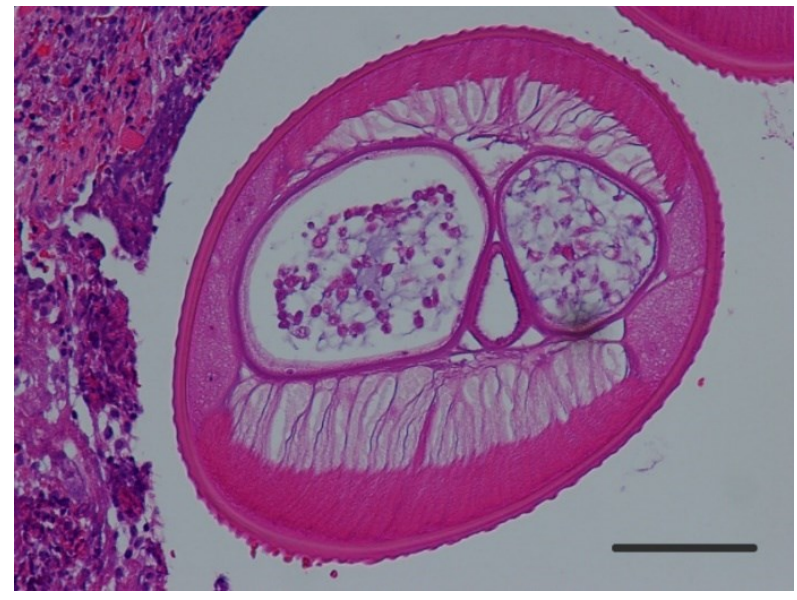

Fig. 2. Haematoxylin and eosin-stained cross-section of $D$. repens; external cuticular ridges are well visible; case 1 . The parasite was photographed using a microscope and DS-Fi1 camera (Nikon). Scale bar: $100 \mu \mathrm{m}$

Table 1. Dogs that tested positive in at least one assay

\begin{tabular}{|c|c|c|c|c|c|c|c|}
\hline $\begin{array}{l}\text { Dog } \\
\text { number }\end{array}$ & Gender & Age (years) & Breed & $\begin{array}{l}\text { History of } \\
\text { travelling }\end{array}$ & Ownership (Region) & $\begin{array}{l}\text { Knott's } \\
\text { test }\end{array}$ & $\begin{array}{l}\text { Dirofilaria species } \\
\text { by real-time PCR }\end{array}$ \\
\hline 76 & male & 12 & mixed & none & private (Mura river region) & positive & D. repens \\
\hline 389 & male & 2 & GSP & $\mathrm{DE}$ & State police (Ljubljana) & negative & D. repens \\
\hline 390 & female & 1 & GSP & none & State police (Ljubljana) & positive & D. repens \\
\hline
\end{tabular}

GSP - German shorthaired pointer; DE - Denmark

Table 2. Demographic and clinical data of the human cases described in this study

\begin{tabular}{|c|c|c|c|c|c|c|c|}
\hline Case & Gender & $\begin{array}{l}\text { Age } \\
\text { (years) }\end{array}$ & Region & $\begin{array}{l}\text { Year of established } \\
\text { diagnosis }\end{array}$ & $\begin{array}{l}\text { Site } \\
\text { of infection }\end{array}$ & Isolate & Species identified \\
\hline 1 & Female & 20 & Central Slovenia (Ljubljana) & 2010 & N/A & Subcut. nodule & D. repens \\
\hline 2 & Female & 45 & $\begin{array}{l}\text { North East Slovenia } \\
\text { (Mura river region) }\end{array}$ & 2013 & Breast & Subcut. nodule & D. repens \\
\hline 3 & Male & 49 & $\begin{array}{l}\text { North East Slovenia } \\
\text { (Mura river region) }\end{array}$ & 2014 & Right upper arm & Subcut. nodule & D. repens \\
\hline 4 & Male & 63 & $\begin{array}{l}\text { North East Slovenia } \\
\text { (Drava river region) }\end{array}$ & 2017 & Scalp & Subcut. nodule & D. repens \\
\hline
\end{tabular}

N/A - data not available; Subcut. - subcutaneous 


\section{Discussion}

The prevalence of Dirofilaria spp. in dogs in Slovenia has not yet been studied. Dirofilaria immitis was first described in Slovenia in 1987, when D. immitis was found postmortem in the right ventricle and pulmonary artery of a dog (3). Dirofilaria repens was described only one year later in a Slovenian red fox (4). In Slovenian dogs, D. repens was described for the first time in 2011 by German authors who detected it in dogs imported from Slovenia to Germany (22). Clinical reports have also recorded sporadic cases of $D$. immitis and D. repens in Slovenian dogs $(23,24)$. In clinical cases of cardio-pulmonary signs in dogs with suspected heartworm infestation, a rapid heartworm antigen test is usually performed to confirm $D$. immitis infection. Adult worms may also be visualised by ultrasound in the heart in the late stages of the disease or are occasionally found postmortem $(3,20)$. If subcutaneous nodules are found, adult or juvenile worms may be extracted from the nodule and their morphology studied. In the laboratory of parasitology at the Institute of Microbiology and Parasitology in the Veterinary Faculty of the University of Ljubljana, some juvenile or adult $D$. repens have been determined in the last decade on the basis of extracted worms. Morphological assessment can also be performed on histopathological sections of excised nodules. However, the problem is that most D. repensinfected dogs are asymptomatic (11).

If microfilariae are found in the bloodstream, the species can be accurately determined morphologically as $D$. immitis or D. repens, according to a recent study (19). Unfortunately, microfilariae can easily be missed in the blood if they are present in small numbers. In addition, microfilariae do not circulate in the bloodstream throughout the day because of circadian fluctuations. Taking a blood sample in the evening and using the Knott's test will increase the chance of finding microfilariae. In case of doubt about the species due to the similar morphology of $D$. repens and D. immitis, a rapid test can be performed to confirm $D$. immitis or a PCR can be undertaken to distinguish between the two species (6).

Our study confirmed a prevalence of $0.64 \%$ of D. repens infection in dogs in Slovenia. This prevalence is rather low compared to those of the surrounding countries of Slovenia. The reported prevalence for Croatia ranges from $14.0 \%$ to $47.3 \%$ (34), for Hungary from $11.1 \%$ to $30.0 \%(7,8)$ and for Italy from $1.5 \%$ to $30 \%(5,28,33)$. The variation in prevalence across neighbouring countries is quite large, which was a challenge in creating a response distribution for a sample for our study.

A recent retrospective study reported 146 dogs living in Austria that tested positive for D. immitis and/or D. repens from 1998 to 2018. Among these dogs, 99 were diagnosed with $D$. immitis infection, 37 with D. repens, and 10 dogs had coinfection with both nematodes. Eight D. repens-positive dogs had no recorded travel history and originated from Austria (29). Another study reported possible autochthonous cases of $D$. repens in one human, seven dogs, and two mosquito species in Austria (9). This finding suggests that the parasite has become endemic and established in this country, which borders Slovenia. Potentially autochthonous infections in dogs were reported from eastern Austria in the border areas with Slovakia and Hungary, which may indicate spread from east to west.

Although it does not directly border Slovenia, Serbia is one of the most dirofilariasis-affected countries in the Balkans, where D. repens has been found in dogs with prevalence ranging from $17.0 \%$ to $49.0 \%$ (6). Recently, increased importation of rescued and nonrescued dogs from Serbia to Slovenia has been noted. This is important from the perspective of the endemic spread of the disease.

The epidemiological data of the positive dogs in our study showed that two out of three had not travelled abroad in their lifetime (Table 1). These two cases could be autochtonous. If it is not already, the disease may become endemic in Slovenia at any time. A xenodiagnosis carried out in 2012 in a northern part of Italy only $200 \mathrm{~km}$ from the Slovenian border proved the endemic presence of $D$. repens in mosquitoes (17). Northern Italy is considered the most endemic area in the world (33). Duly considering epidemiological mapping of past and present zoonotic diseases, our data show that preventive measures should be strictly applied to dogs within Slovenia and not only when dogs travel abroad.

Considering D. repens infection in humans, more than 3500 cases were reported in Europe from 1977 to 2016 (11). Italy, which borders Slovenia to the west, is the country with the highest number of described human clinical cases in Europe and the circulation of D. repens still seems to be growing (10). Human D. repens infection is considered an emerging zoonosis in Hungary (6). In Croatia, which borders Slovenia to the east, the first description of a human case in a patient with a travel history was reported in 1996, but the first autochthonous case was confirmed in 2003. Since these initial reports, a total of 30 cases of human dirofilariasis caused by D. repens have been described in Croatia. Until 2007, all human cases in Croatia had been reported only from the coastal region. Since then, the number of cases in the continental region has steadily increased, and the geographical distribution now appears to be almost identical. The possible explanation for the occurrence of human dirofilariasis in the continental region of Croatia is the expansion of the host range of the competent vector species Aedes albopictus and Aedes japonicus (25).

In Slovenia, the first case of human D. repens infection was diagnosed in 1998 and reported by Logar et al. (18). The authors believed that the case was not autochthonous. The infection with $D$. repens in this case was most likely acquired in the Canary Islands, Spain, seven months before the subcutaneous nodule was diagnosed (18). The first case of $D$. repens infection 
which was beyond doubt autochthonous was detected in 2008 in a female patient from the coastal region of Slovenia with no travel history (13). The travel history of the four patients with subcutaneous dirofilariasis diagnosed in the Institute of Microbiology and Immunology from 2010 to 2020 is not known. Interestingly, three of the cases originated from northeastern Slovenia, more specifically from the basins of the Drava and Mura rivers, whence one of the infected dogs from our study, which had never left the country, also originated. One of the human cases was from Ljubljana, the capital of Slovenia, where two of the infected dogs were found. However, it should be noted that many Slovenians spend their holidays in Croatia, which is known to be endemic for dirofilariasis. Therefore, the human patients presented in our study could have been infected abroad. A nationwide screening for filaroid parasites in mosquitoes in Slovenia, currently ongoing within the "Establishment of monitoring of vectors and vector-borne diseases in Slovenia" research project funded by the Slovenian Research Agency, will shed light on the importance and extent of possible autochthonous transmission of dirofilariasis in Slovenia.

The absence of clinical signs in the majority of D. repens infections in dogs and the difficulty in diagnosing the infection due to the lack of serological tests favour the further spread of this species (11). Unlike D. immitis infection, for which several simple and rapid commercial serological diagnostic tests are available to clinics, no specific serological tests are available for $D$. repens. Clinicians can use microscopic examination of direct blood smears, but the use of the Knott's test is preferable. This test is more sensitive because it concentrates the microfilariae, making them less likely to be missed (27). Since only L1 larvae of $D$. repens can be found in the blood of hosts (33), the positive Knott's test in our dogs and species identification proves the presence of adult nematodes somewhere in the dogs' bodies. According to the literature, adult nematodes are rarely found, occasionally being recovered from skin nodules (32). Follow-up was performed on all three infested dogs from our study. Based on information from a telephone interview, all infected dogs remained asymptomatic despite not being treated with an adulticide. Dog number 76 was euthanised one year after participation in the study because of old age. Both police dogs continued to work and showed no clinical signs for the following 3 years. These findings are at odds with the results of Tarello (33), whose retrospective study of 100 dogs with D. repens infection showed the presence of pruritus in all dogs at least during each summer to autumn season and the manifestation of many other clinical signs in varying percentages.

A study conducted on 171 canine blood samples from eight European countries proved that measuring the length and width of microfilariae using the Knott's test clearly distinguished between $D$. immitis, D. repens and Acanthocheilonema spp. (19). PCR is nevertheless the method that is nowadays considered the most sensitive and accurate tool for the detection and differentiation of microfilariae. The high morphological similarity between certain filarial species makes morphometric analyses of microfilariae in blood unreliable, especially in mixed infections or in cases with low parasitaemia (6). This was also the case in our study: in the two Knott's test-positive cases it was not possible to determine the species by morphometric analyses, but this was easily determined by PCR. Furthermore, worms were detected by PCR in a dog with parasitaemia too low to be detected by Knott's test. The detection limit of the pan-filarial real-time PCR that was used is reported to be $1.5 \times 10^{-4}$ microfilariae $/ \mathrm{mL}$ (15), while studies show that Knott's test is only capable of detecting dogs with much higher microfilaraemia (26). The use of the modified Knott's test alone may therefore result in many false-negative diagnoses. In order to prevent endemicity in new regions, the implementation of molecular techniques in the diagnosis of canine filariosis in clinical practice should be recommended $(22,26)$.

Regarding the diagnosis of human subcutaneous dirofilariasis, serological tests are not helpful, as microfilariae only exceptionally develop in humans, and it is these which trigger immunological reactions (6). With no microfilariae present, microscopic analysis or PCR of blood samples is also not useful. The diagnosis is mainly based on histopathological findings of excised nodules. The most discriminative features of $D$. repens are the longitudinal cuticular ridges, which are not present in any other filarial nematode infecting humans in the Mediterranean region (6). Indeed, these longitudinal ridges were detected on the external part of the cuticle of all the filariae infecting our patients, confirming $D$. repens infection, although the morphological diagnosis was not verified by molecular tools.

Prevalence surveys of $D$. repens infection in Slovenian dogs have not been conducted. Detailed epidemiological mapping of dirofilariasis is important to develop a rational approach to prevention of the disease. Regular preventive use of macrocyclic lactones and treatment of all carrier dogs with adulticidal drugs is imperative to reduce the burden of dirofilariasis in dogs and thus reduce the risk of infection in humans. We believe that the results of our study add important data to the European epidemiological map of the disease.

From our data, we conclude that the prevalence of D. repens in Slovenian dogs is rather low $(0.64 \%)$, but Slovenia may already be an endemic country. Therefore, as a sufficient preventive measure, we recommend the use of contact insecticides in dogs throughout the mosquito season together with periodic application of oral macrocyclic lactones during the main mosquito season. All dogs infested with microfilariae should be treated with adulticidal medication. These protocols should be adjusted to the epidemiologic situation, which may change at any time. Further studies are warranted. 
Conflict of Interests Statement: The authors declare that there is no conflict of interests regarding the publication of this article.

Financial Disclosure Statement: We gratefully acknowledge funding from the Slovenian Research Agency, from programme P4-0053 for T. Kotnik, programme P3-0083 for B. Šoba and programme P4-0092 for A. Vergles Rataj. The funders had no influence on the study design, data collection and analysis, decision to publish, or preparation of the manuscript.

Animal Rights Statement: The project was reviewed and approved by the Ethics Committee of the Veterinary Faculty, University of Ljubljana. Informed consent from dog owners was provided for each specimen. Collection of the human material examined was in accordance with the legal regulations of Slovenia.

Acknowledgements: We thank Dr. Bernard Davoust from IHU Méditerranée Infection and Aix-Marseille University, Marseille, France, for providing sections of $D$. immitis and D. repens nematodes, the DNA of which we used as positive controls in the real-time PCRs. We thank Mateje Nagode for help with study design and statistical analysis of the data. We would like to thank all dog owners for their participation and our veterinary colleagues in the field for sampling the dogs' blood.

\section{References}

1. Anderson R.C., Bain O.: Keys to genera of the order Spirurida. Part 3. Diplotriaenoidea, Aproctoidea and Filarioidea. In: Keys to the Nematodes Parasites of Vertebrates, edited by R.C. Anderson, A.G. Chabaud, S. Willmott, CABI Publishing, Wallingford, 1976, pp. 59-116.

2. Bajer A., Mierzejewska E.J., Rodo A., Bednarska M., Kowalec M., Welc-Falęciak R.: The risk of vector-borne infections in sled dogs associated with existing and new endemic areas in Poland: Part 1: A population study on sled dogs during the racing season. Vet Parasitol 2014, 202, 276-286, doi: 10.1016/j.vetpar.2013.12.033.

3. Brglez J., Šenk L.: Dirofilaria immitis (Leidy, 1856) Railliet et Henry, 1911, pri psu (Diorofilaria immitis (Leidy, 1856) Railliet et Henry, 1911, in a dog - in Slovene). Zb Bioteh Fak Univ Edvard Kardelj Ljubljana, Veterinarstvo 1987, 24, 69-72.

4. Brglez J., Verbančič Š.: Podkožna oblika dirofilarioze pri lisici (Subcutaneous dirofilariasis in a red fox - in Slovene). Zb Bioteh Fak Univ Edvard Kardelj Ljubljana, Veterinarstvo 1988, 25, 53-56.

5. Brianti E.: Italian nationwide survey on filariosis and angiostrongilosis. Oral Presentation 16, Proceedings of the $6^{\text {th }}$ European Dirofilaria and Angiostronglylus Days, Belgrade, Serbia, July 5-7, 2018. Parasites Vectors 2018, 11 (Suppl 1), O16. http://hdl.handle.net/11588/727030

6. Capelli G., Genchi C., Baneth G., Bourdeau P., Brianti E., Cardoso L., Danesi P., Fuehrer H.-P., Giannelli A., Ionică A.M., Maia C., Modrý D., Montarsi F., Krücken J., Papadopoulos E., Petrić D., Pfeffer M., Savić S., Otranto D., Poppert S., Silaghi C.: Recent advances on Dirofilaria repens in dogs and humans in Europe. Parasites Vectors 2018, 11, 663, doi: 10.1186/s13071018-3205-x.
7. Farkas R., Mag V., Gyurkovszky M., Takács N., Vörös K., Solymosi N.: The current situation of canine dirofilariosis in Hungary. Parasitol Res 2020, 119, 129-135, doi: 10.1007/s00436019-06478-5.

8. Fok É., Farkas R., Kiss G., Majoros G., Jacsó O., Gyurkovszky M. Preliminary results of an epidemiological survey on dirofilariosis of dogs and cats in Hungary. In: Mappe parassitologiche 8 Dirofilaria immitis and D. repens in dog and cat and human infections, edited by C. Genchi, L. Rinaldi, G. Cringoli, Rolando Editore, Naples, 2007, pp. 195-196.

9. Fuehrer H.P., Auer H., Leschnik M., Silbermayr K., Duscher G., Joachim A.: Dirofilaria in Humans, Dogs, and Vectors in Austria (1978-2014) - From Imported Pathogens to the Endemicity of Dirofilaria repens. PLoS Negl Trop Dis 2016, 10, e0004547, doi: 10.1371/journal.pntd.0004547.

10. Gabrielli S., Mangano V., Furzi F., Oliva A., Vita S., Poscia R., Fazii P., Di Paolo J., Marocco R., Mastroianni C.M., Bruschi F., Mattiucci S.: Molecular Identification of New Cases of Human Dirofilariosis (Dirofilaria repens) in Italy. Pathogens 2021, 10 , 251, doi: 10.3390/pathogens10020251

11. Genchi C., Kramer L.H.: Subcutaneous dirofilariosis (Dirofilaria repens): an infection spreading throughout the old world. Parasites Vectors 2017, 10 (Suppl 2), 517, doi: 10.1186/s13071-017-2434-8.

12. Genchi C., Kramer L.H., Sassera D., Bandi C.: Wolbachia and its implications for the immunopathology of filariosis. Endocr Metab Immune Disord Drug Targets 2012, 12, 53-56, doi: 10.2174/187153012799279108.

13. Knez L., Kotar T.: Človeška podkožna dirofilarioza, povzročena z Dirofilaria repens (Human subcutaneous dirofilariasis caused by Dirofilaria repens - in Slovene). Pot Med 2009, 48, 161-162.

14. Kotnik T., Moreno J., Šoba B., Krt B., Skvarč M., Vergles Rataj A., Gorišek Bajc M., Ravnik Verbič U: Canine leishmaniasis prevalence in the Slovenian dog population. J Vet Res 2021, 65, 161-168, doi: 10.2478/jvetres-2021-0028.

15. Laidoudi Y., Davoust B., Varloud M., Niang E.H.A., Fenollar F., Mediannikov O.: Development of a multiplex qPCR-based approach for the diagnosis of Dirofilaria immitis, D. repens and Acanthocheilonema reconditum. Parasites Vectors 2020, 13, 319 , doi: 10.1186/s13071-020-04185-0

16. Laidoudi Y., Marie J.L., Tahir D., Watier-Grillot S., Mediannikov O., Davoust B.: Detection of Canine Vector-Borne Filariasis and Their Wolbachia Endosymbionts in French Guiana. Microorganisms 2020, 8, 770, doi: 10.3390/ microorganisms 8050770 .

17. Latrofa M.S., Montarsi F., Ciocchetta S., Annoscia G., Dantas-Torres F., Ravagnan S., Capelli G., Otranto D.: Molecular xenomonitoring of Dirofilaria immitis and Dirofilaria repens in mosquitoes from north-eastern Italy by real-time PCR coupled with melting curve analysis. Parasites Vectors 2012, 5, 76, doi: 10.1186/1756-3305-5-76

18. Logar J., Novšak V., Rakovec S., Staniša O.: Subcutaneous infection caused by Dirofilaria repens imported to Slovenia. J Infect 2001, 42, 72-74, doi: 10.1053/jinf.2000.0759.

19. Magnis J., Lorentz S., Guardone L., Grimm F., Magi M., Naucke T.J., Deplazes P.: Morphometric analyses of canine blood microfilariae isolated by the Knott's test enables Dirofilaria immitis and D. repens species-specific and Acanthocheilonema (syn. Dipetalonema) genus-specific diagnosis. Parasites Vectors 2013, 6, 48, doi: 10.1186/1756-3305-6-48.

20. Milosavljević P., Kulišić Z.: First cases of dirofilariasis in dogs in Yugoslavia. Vet Glas 1989, 43, 71-76.

21. Pampiglione S., Rivasi F.: Human dirofilariasis due to Dirofilaria (Nochtiella) repens: an update of world literature from 1995 to 2000. Parassitologia 2000, 42, 231-254.

22. Pantchev N., Etzold M., Daugschies A., Dyachenko V.: Diagnosis of imported canine filarial infections in Germany 2008-2010. Parasitol Res 2011, 109 (Suppl 1), S61-S76, doi: 10.1007/s00436011-2403-7.

23. Pogorevc E., Suhadolc Scholten S., Domanjko Petrič A., Tozon N.: Eozinofilni pnevmonitis - oblika dirofilarioze pri psu klinični primer (Eosinophilic pneumonitis - case report of 
dirofilariasis in a dog - in Slovene) In: Zbornik referatov $X X$. Simpozij o aktualnih boleznih malih živali, 2007, 76-77.

24. Praprotnik Borko Š.: Okužba z Dirofilario repens pri dveh psih (Dirofilaria repens infection in two dogs - in Slovene). In: Zbornik referatov XXXI. Simpozij o aktualnih boleznih malih živali, 2018, 63-64.

25. Pupić-Bakrač A., Pupić-Bakrač J., Jurković D., Capar M., Lazarić Stefanović L., Antunović Ćelović I., Kučinar J., Polkinghorne A., Beck R.: The trends of human dirofilariasis in Croatia: Yesterday - Today - Tomorrow. One Health 2020, 10, 100153, doi: 10.1016/j.onehlt.2020.100153.

26. Rojas A., Rojas D., Montenegro V.M., Baneth G.: Detection of Dirofilaria immitis and other arthropod-borne filarioids by an HRM real-time qPCR, blood-concentrating techniques and a serological assay in dogs from Costa Rica. Parasites Vectors 2015, 8, 170, doi: 10.1186/s13071-015-0783-8.

27. Sabūnas V., Radzijevskaja J., Sakalauskas P., Petkevičius S., Karvelienė B., Žiliukienė J., Lipatova I., Paulauskas A.: Dirofilaria repens in dogs and humans in Lithuania. Parasites Vectors 2019, 12, 177, doi: 10.1186/s13071-019-3406-y.

28. Sed G., Morchón R., Magi M., Simón F., Macchioni F.: Epidemiological study on canine filariasis on the border between Lazio and Tuscany (Italy). Poster 9, Proceedings of the $6^{\text {th }}$ European Dirofilaria and Angiostronglylus Days, Belgrade, Serbia, July 5-7, 2018. Parasit Vect 2018, 11 (Suppl 1), P9, doi: 10.1186/s13071-018-3183-z.
29. Sonnberger K., Duscher G.G., Fuehrer H.P., Leschnik M.: Current trends in canine dirofilariosis in Austria - do we face a preendemic status? Parasitol Res 2020, 119, 1001-1009, doi: 10.1007/s00436-019-06576-4.

30. Tahir D., Davoust B., Parola P.: Vector-borne nematode diseases in pets and humans in the Mediterranean Basin: An update. Vet World 2019, 12, 1630-1643, doi: 10.14202/vetworld.2019.16301643.

31. Tarello W.: Cutaneous lesions in dogs with Dirofilaria (Nochtiella) repens infestation and concurrent tick-borne transmitted diseases. Vet Dermatol 2002, 13, 267-274, doi: 10.1046/j.1365-3164.2002.00305.x

32. Tarello W.: Dermatitis associated with Dirofilaria repens microfilariae in a dog from Rome. Vet J 2003, 165, 175-177, doi: 10.1016/s1090-0233(02)00243-5.

33. Tarello W.: Clinical aspects of dermatitis associated with Dirofilaria repens in pets: a review of 100 canine and 31 feline cases (1990-2010) and a report of a new clinic case imported from Italy to Dubai. J Parasitol Res 2011, 578385, doi: $10.1155 / 2011 / 578385$

34. Tasić-Otašević S.A., Trenkić Božinović M.S., Gabrielli S.V., Genchi C.: Canine and human Dirofilaria infections in the Balkan Peninsula. Vet Parasitol 2015, 209, 151-156, doi: 10.1016/j.vetpar.2015.02.016. 